\title{
The COVID-19 pandemic: an opportunity to strengthen health systems in Afghanistan
}

Umerdad Khudadad, ${ }^{1}$ Najibullah Safi, ${ }^{2}$ Wafa Aftab, ${ }^{3}$ Asrar Ali, ${ }^{1}$ and Sameen Siddiqi ${ }^{3}$

${ }^{1}$ Department of Emergency Medicine, Aga Khan University, Karachi, Pakistan. ${ }^{2}$ Health System Development, World Health Organization Country Office, Kabul, Afghanistan. ${ }^{3}$ Department of Community Health Sciences, Aga Khan University, Karachi, Pakistan. (Correspondence to: Umerdad Khudadad: umerhaideri47@gmail.com).

Citation: Khudadad U; Safi N; Aftab W; Ali A; Siddiqi S. The COVID-19 pandemic: an opportunity to strengthen health systems in Afghanistan. East Mediterr Health J. 2021;27(3):220-223. https://doi.org/10.26719/emhj.21.007

Received: 21/07/20; accepted: 03/02/21

Copyright (C) World Health Organization (WHO) 2021. Open Access. Some rights reserved. This work is available under the CC BY-NC-SA 3.o IGO license (https://creativecommons.org/licenses/by-nc-sa/3.o/igo).

\section{Introduction}

Afghanistan's health care system has already been strained by four decades of conflict and is now being threatened by the arrival of COVID-19. As of 7 February 2021, 106 million cases of COVID-19 and 2.31 million deaths have been reported in more than 180 countries (1). The readiness of Afghanistan's healthcare system to respond rapidly and effectively to the outbreak of COVID-19 remains limited.

The first case of COVID-19 in Afghanistan was reported on February 24, 2020, from the province of Herat that shares a border with the Islamic Republic of Iran (1). Since then, the number of confirmed cases of COVID-19 in Afghanistan has risen. As of 7 February 7 2021, there have been 55335 confirmed cases with 2410 deaths in Afghanistan (2). According to the Herat provincial representative, 1000 Afghans return from the Islamic Republic of Iran every day and initial cases were reported among these returnees followed by community transmission across the country due to a lack of virus containment measures at the border (3). However, limited testing capacity means the number of reported cases remained low in Afghanistan. To date, Afghanistan has carried out 264791 tests in a country of 36.6 million, and the number of confirmed cases is directly linked to the availability of functional laboratories in the provinces (Figure 1). Since 24 February 2020, the number of reported cases has increased as laboratory capacity has increased. Of the total number of cases, $73 \%$ are reported from 6 provinces (Kabul, Nangahar, Paktya, Kandahar, Herat and Balkh) where functional COVID-19 diagnostic facilities exist.

The International Organization for Migration (IOM) and the United Nation High Commission for Refugees (UNHCR) confirmed that nearly 1000 Afghans are returning from the Islamic Republic of Iran each day (3). Before containing the spread of COVID-19 by control measures, including border closure, as of 7 January 2021, just 1200 of the 200000 returnees had been tested for the virus. The transmission of the virus in the context of Afghanistan should have been consistently high given the country's unique vulnerabilities, including porous boundaries, frequent cross-border movements, weak health system, high malnutrition rate, limited water and sanitation facilities, inequality in access to health-care services, gender-based violence, limited movement of women and high numbers of people with special needs (4). In addition, the ongoing conflicts in Afghanistan, and particularly in the first quarter of 2020 along with an attack on the Médecins Sans Frontières (MSF) operated

Figure 1 Status of COVID-19 in Afghanistan

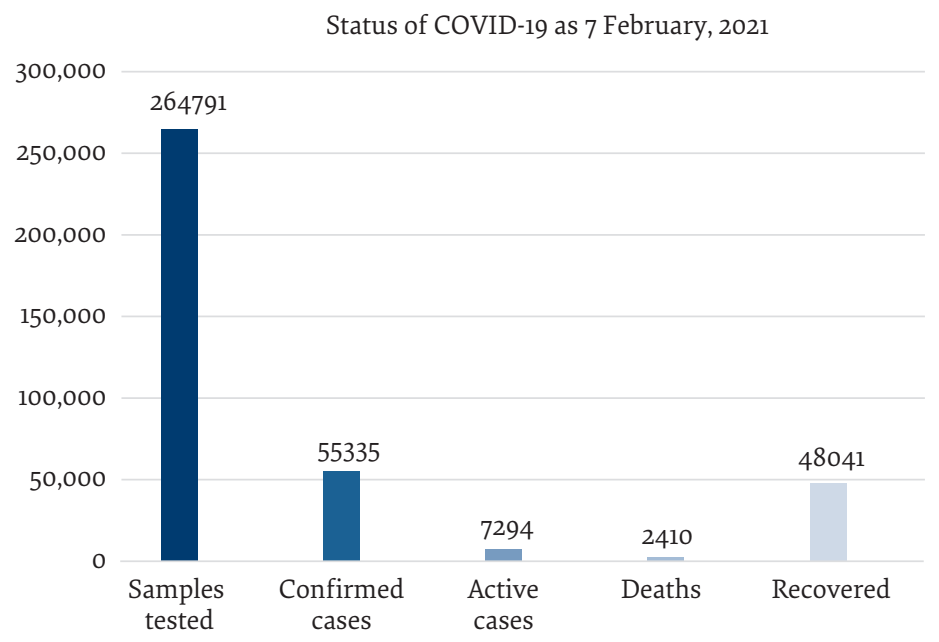


maternity hospital in Kabul, have negatively affected the prevailing fragile health-care system (5) (Figure 2).

Deep social ties, large and extended families, highdensity living, and religious and cultural beliefs make it almost impossible to practice social distancing and other preventive measures, which have contributed to the rapid transmission of the virus (3). In addition, many individuals testing positive are failing to declare their status and self-isolate due to potential social stigma as well as low levels of concern.

\section{Response to the COVID-19 pandemic}

In response to the pandemic the government of Afghanistan closed all schools and universities, banned all religious and traditional public gatherings, closed most businesses and imposed restrictions on free movement. However, all these measures were relatively ineffective as more than $55 \%$ of the population live in poverty, $66 \%$ of the population are engaged in informal employment, and in the absence of a social protection system they have to work since they survive on daily wages. Nonetheless, the economic toll has dominated, with serious consequences for daily wage workers and worsening food security. Some provision of food to low-income families has been made, but defining the eligibility for this provision has led to social tension, and distribution has had a negative impact on preventive measures like social distancing. Moreover, the continuation of lockdown will significantly increase hunger, poverty, and malnutrition, thus possibly causing greater mortality in the long term than the virus itself. The lockdown also reduced the utilization of essential health services, which may result in increased mortality in the long term from measles, diarrhea, and other common communicable and noncommunicable diseases.

The Ministry for Religious Affairs also advocated social distancing during prayers instead of mandating closure for places of worship (7), thus during Ramadan, mosques continued to operate. In addition, a growing community of religious clerics is also advocating mistrust of key health messages around COVID-19. This community has been observed to be growing in the western province of Herat, which has the secondhighest number of reported cases. Contact tracing has also been unsuccessful due to missing or incorrect data on registration forms and follows-ups.

\section{Health system's response}

The outbreak of any infectious disease, including COVID-19, needs a robust surveillance system to detect cases and monitor suspected cases through contact tracing (8). Afghanistan has a national surveillance system that uses four approaches to mitigating the infectious disease prevalence, including identification, investigation of cases, border screening and decentralized testing. These surveillance components have been adapted in response to the COVID-19 pandemic. Nearly 34000 acute flaccid paralysis (AFP) volunteers have been redirected and trained to report suspected cases of COVID-19 to health facilities and rapid response teams (9). Surveillance and risk communication teams are posted at each crossing point on the borders, especially those bordering Pakistan and the Islamic Republic of Iran. Testing has also moved away from reliance on the Central Public Health Laboratory (CPHL) in Kabul, to equipping provincial reference laboratories in Herat, Balkh, Kandahar, Nangarhar, and Paktya. Routine laboratory work has been paused to specifically focus on COVID-19. Currently national processing capacity is around 2000 samples per day with 12 operational laboratories across the country (9). However, there are some contextual issues around the implementation of surveillance. Community perception of a topdown COVID-19 response has been challenging, due to low community awareness of the pandemic and certain segments of society having greater access to tests.

Another challenge that threatens the health-care system of Afghanistan in its response to COVID-19 is the

Figure 2 Civilian casualties in Afghanistan, first quarter 2020

Civilian casualties in Afghanistan, first quarter 2020

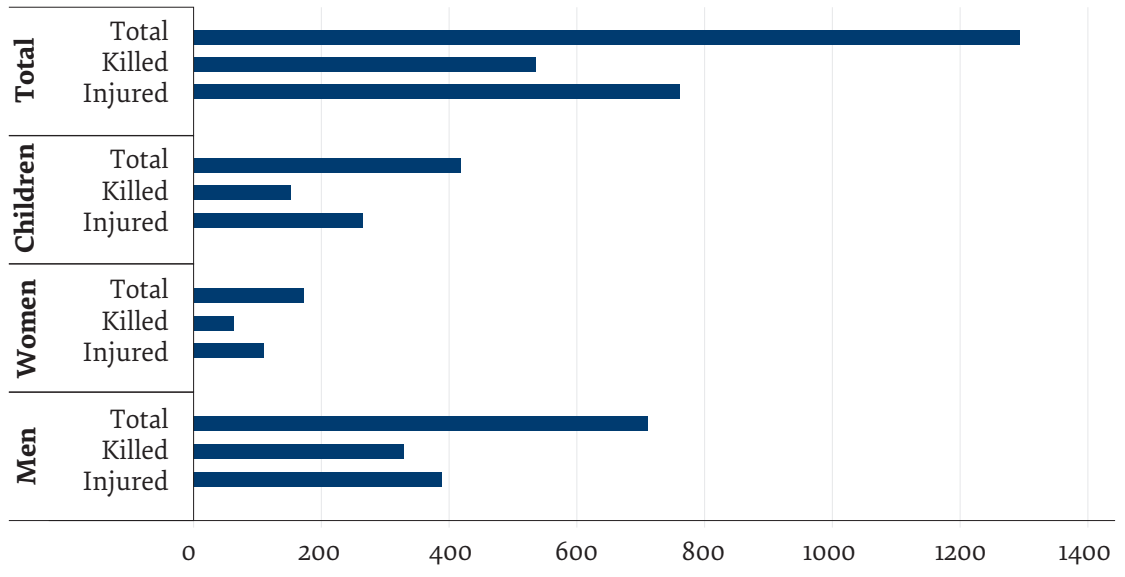

Source: United Nations Assistance Mission in Afghanistan (UNAMA) (6) 
shortage of health-care workers. There are only 9.4 skilled health workers (nurses, midwives and paramedics) and 1.9 physicians per 10000 population (10). According to the World Health Organization Global Health Workforce Alliance, 23 skilled health workers per 10000 people are required to carry out all critical health functions (11). This challenge is increased by the lack of personal protective equipment and low level of security in the remote areas of Afghanistan. This has a significant, immediate and adverse impact on the delivery and availability of healthcare facilities to both the general population and healthcare workers.

Much of the health-care services in Afghanistan are financed through international organizations. In terms of funding to support the COVID-19 response, the World Bank allocated an additional funding of US\$ 100.4 million for strengthening coordination, surveillance, laboratories, provision of supplies, capacity building, Rapid Response Teams and continuation of essential health services. Rapid Response Team implementation in 31 out of 34 provinces is contracted out to nongovernmental organizations using US\$ 46 million funding (of the total US\$100.4 million) to strengthen isolation wards, case management and the continuation of existing essential services. A multi-sector humanitarian country plan for COVID-19 in Afghanistan was finalized in late March 2020 , requiring US\$108.1 million, to provide 6.1 million people across all clusters with life-saving assistance. This strategic funding was based on response to the activities for up to three months from the beginning of the pandemic (12). However, it is challenging to utilize these funds effectively in response to a COVID-19 plan for Afghanistan.

\section{Recommendations}

Afghanistan is facing several challenges in the face of the COVID-19 pandemic and needs comprehensive strate- gic actions to control further transmission of the virus. Afghanistan requires a multisectoral response effort to strengthen and expand the control measures including country-level coordination, robust surveillance, expanding laboratory capacity, communicating risks, and engaging communities. One recommendation could be an establishment of a crisis management team in government, with the potential of analyzing and monitoring trends in the country to ensure a wider multi-sectoral preparedness response. It is also important to reinforce the continuation of all non-pharmaceutical interventions that include practicing frequent handwashing, following respiratory etiquettes, social distancing and wearing masks.

Afghanistan needs a more systematic approach to social protection. The pandemic has provided Afghanistan with an opportunity to establish a vulnerability-based comprehensive social protection system that provides information on geographic and wealth distribution of the population to tackle the issue of financial disparities and inequalities. Protecting the lower wealth quintiles will allow the country to cope with future crises effectively.

It is equally important that the Afghanistan government along with donors and partners should recognize the significance of community-level engagement in war-ridden areas of the country for effective, culturally sensitive, and demand-driven participatory response to COVID-19. The long-term effect of such engagement would also positively impact the peace process in the country. In addition, Funding agencies and donors needs to strengthen the system of accountability to allow the effective utilization of funds and aids. The utilization of funds needs to be more directed towards local needs and preparing health system to response effectively against adversities.

\section{References}

1. World Health Organization. Coronavirus disease 2019 (COVID-19): situation report, 61. Geneva: World Health Organization; 2020.

2. World Health Organization. Coronavirus disease 2019 (COVID-19): situation report, 72. Geneva: World Health ORganization; 2020.

3. Mehrdad E. T How Afghanistan failed to contain COVID-19. The Diplomat. March 27, 2020 (https://thediplomat.com/2020/03/ how-afghanistan-failed-to-contain-covid-19/).

4. Shah J, Karimzadeh S, Al-Ahdal TMA, Mousavi SH, Zahid SU, Huy NT. COVID-19: the current situation in Afghanistan. The Lancet Global Health. 2020;8(6) https://doi.org/10.1016/S2214-109X(20)30124-8

5. Kazemi SR, Muzhary F. Covid-19 in Afghanistan (4): A precarious interplay between war and epidemic. Afghanistan Analysts Network. 19 June 2020. (https://www.afghanistan-analysts.org/en/reports/war-and-peace/covid-19-in-afghanistan-4-a-precarious-interplay-between-war-and-epidemic/).

6. United Nations Assistance Mission in Afghanistan (UNAMA). More than 500 civilians killed in Afghanistan conflict during first quarter 2020. 27 April 2020 (https://unama.unmissions.org/more-500-civilians-killed-afghanistan-conflict-during-first-quarter-2020).

7. Ansar M. Afghan clerics ban religious, political gatherings amid COVID-19. TOLO News. 6 April 2020. (https://tolonews.com/ health/afghan-clerics-ban-religious-political-gatherings-amid-covid-19). 
8. Khademian Z, Sharif F, Tabei SZ, Bolandparvaz S, Abbaszadeh A, Abbasi HR. Teamwork improvement in emergency trauma departments. Iran J Nurs Midwifery Res. 2013;18(4):333-9.

9. United Nations Office for the Coordination of Humanitarian Affairs (OCHA). Afghanistan COVID-19 multi-sectoral response: operational situation report. 2 September 2020 (https://reliefweb.int/sites/reliefweb.int/files/resources/operational_sitrep_covid-19_2_september_2020_final.pdf).

10. Islamic Republic of Afghanistan National Statistics and Information Authority (NSIA). Afghanistan Statistical Yearbook 2018-19. July 2019. Kabul: NSIA; 2019 (https://www.nsia.gov.af:8080/wp-content/uploads/2019/11/Afghanistan-Statistical-Yearbook-2018-19_compressed.pdf).

11. World Health Organization. A universal truth: no health without a workforce. Geneva: World Health Organisation; 2013:1-104 (https://www.who.int/workforcealliance/knowledge/resources/hrhreport2013/en/).

12. World Health Organization. Afghanistan Brief: COVID-19 No. 19 (25 March 2020). Geneva: World Health Organization; 2020 (https://www.who.int/workforcealliance/knowledge/resources/hrhreport2013/en/). 